\title{
One Officer Factory:The Royal Military College and Officer Education since 1955
}

\section{Randall Wakelam}

\begin{abstract}
:
This article describes how between 1955 and 2000 the Royal Military College developed and operated a range of undergraduate and graduate degree programmes which satisfied the learning needs of the Canadian Forces. In so doing the College, actually a degree granting university with a charter from the province of Ontario, was able to meet the educational vision laid down in 1969 shortly after the three military services had been unified. More fundamentally, it shows how senior military leaders and the faculty of RMC were able to work together to provide the military profession with the intellectual skills and professional knowledge to deal with complex and often ambiguous security and defence challenges.
\end{abstract}

\section{RÉSUMÉ:}

Cet article décrit comment, entre 1955 et 2000, le Collège militaire royal (CMR) a développé et mis en œuvre plusieurs programmes de premier cycle et d'études supérieures pour satisfaire aux besoins de formation des Forces armées canadiennes. En vertu d'une charte de la province de l'Ontario, ce collège fut autorisé à offrir des grades universitaires et put ainsi réaliser les objectifs en éducation formulés en 1969, peu de temps après l'unification des trois corps d'armée. Plus fondamentalement, ce texte montre comment les leaders militaires et les professeurs du CMR ont travaillé ensemble pour doter la profession militaire de compétences intellectuelles et de savoirs professionnels afin d'affronter les défis complexes et souvent ambigus de la sécurité et de la défense.

The Royal Military College was opened in 1876 at Kingston as a means to prepare young Canadians for military service as commissioned officers either in the Canadian Militia or in military forces across the British Empire. Not all went on to a military career; some ended up in the North West Mounted Police or in other government related jobs. While the programme was four years in length, no degree was awarded, but graduates left with a strong ability in engineering as well as a solid grounding in the humanities. ${ }^{1}$ In this regard the original programme was not unlike those offered at West Point in the United States or the Royal Military Academy at Woolwich in Britain. RMC would operate in this fashion for much of its first 75 years before expanding its mandate to become a complete postsecondary institution offering 
degrees at the bachelors, masters and doctoral levels.

The military, like any other profession, requires its members to be well-educated. That education consists of blend of liberal arts and more focused professional learning dealing with the competencies specific to professional practice. In the military, the latter has been provided over the centuries by various forms of training necessary to operate equipment, work in groups and ultimately, if necessary, conduct combat operations. But officers, the leaders and managers of the profession, need that broad liberal education in order to make the value judgments and to do the critical thinking needed in all aspects of the organization. This article argues that the Royal Military College of Canada has since the 1950s responded to that learning outcome through the provision of a range of graduate and undergraduate degrees designed to provide officers with the intellectual ability to deal with what the German military philosopher Karl von Clausewitz called the "fog and friction" of military operations, and with the equally complex machinations of peacetime defence management.

The range of education programmes needed by the Canadian military in the last decades of the twentieth century was first articulated in the late 1960s and it is appropriate to jump ahead to that time in order to define a metric for RMC's effectiveness. At that time, as Canada set about to unify its three services into what is now the Canadian Forces, the Chief of Defence Staff (CDS), General Jean-Victor Allard, commissioned an extensive study of officer professional development and education. The task had three major components: there was a need to define what challenges the nation and the military might face, to define what the officer of the future would look like from the perspectives of knowledge, skills and intellectual capacity, and from these to define the fundamental learning requirements which officers would need to meet at various point throughout their new unified careers. Only once these issues had been defined could an adequate education system be fashioned to meet the learning needs of the profession.

After approximately two years of work, The Report of the Officer Development Board ${ }^{2}$ was approved by Allard in March 1969. In the foreword of the report (actually the first of three comprehensive volumes which dealt with the requirement, the structure and functions of the new system, and finally its implementation), the CDS stated clearly the importance he placed on professional competency and education: "It matters little whether the Forces have their present manpower strength, or half them, or double them; without a properly educated, effectively trained, professional officer corps the Forces would, in the future, be doomed to, at the best, mediocrity; at the worst disaster." 3

The basic premise for officer professional development was that all officers needed not just the typical training in equipment, tactics and processes but a broad and continuing education which would give them the intellectual tools necessary to deal with complex and often ambiguous situations. The fundamental building block of this intellectual capacity was a university degree and Maj.-Gen. Roger Rowley, who had authored the report, recommended that all officers have a bachelor's degree from the outset of their service careers. ${ }^{4}$ Beyond the need for the associated intellectual skills Rowley also recognized that there was going to be increasing competition for the best 
and brightest minds from other segments of Canadian society. By building a degree into the recruiting criteria for new officers the CF would have some degree of assurance that it was drawing from the best candidate pool possible. ${ }^{5}$ Once graduated and commissioned, other education would be needed from time to time as the officer advanced in rank and responsibility.

While Rowley and those working with him recognized the importance of training and the development of technical competencies in various trades such as pilot or maritime engineer, they would have and did recognize the fundamental requirement for all officers, regardless of the job being done, to have a sufficient intellectual capacity to deal with uncertainty and ambiguity. This requirement was based on anecdotal observations of the officer corps both during the Second World War and the first two decades of the Cold War. During both episodes the challenges placed before officers of all ranks had been unparalleled in Canadian military experience. In broad societal terms this intellectual capacity equated to the ability to think critically that was and is normally associated with post-secondary education. ${ }^{6}$

The engine for this continuum of education was to be called the Canadian Defence Education Centre (CDEC), which for all intents and purposes would look like a comprehensive Canadian university, if somewhat smaller than most and catering to one particular segment of society. Based in Ottawa it would have three major teaching engines. A Canadian Military College would replace the Royal Military College, and its feeder schools Royal Roads Military College (RRMC) and the Collège Militaire Royale de St-Jean $(\mathrm{CMR})^{7}$, and continue to conduct undergraduate education not unlike what those colleges had been doing since 1959. A Canadian Defence College would provide a series of courses ${ }^{8}$ for commissioned officers: a Junior Staff Course, a Junior Command and Staff Course (for Army Officers); a Command and Staff Course, for mid rank officers; and an Advanced Military Studies Course for senior officers. Finally, the CDEC would "host" a pan-government programme within a National Security College for civilian executives and very senior officers. All of this would be supported by one administrative staff and make use of a central library. ${ }^{9}$

The report also recommended postgraduate education, largely for specialist officers, but also including a "sprinkling of non-specialists" who would profit from in-depth education in any one of the disciplines associated with the military profession. ${ }^{10}$ As well, Rowley foresaw the possibility of aggregating the learning from the professional courses so that an officer could at some point earn a Masters of Military Science. This was not to be a "cereal box" sort of degree but one founded on legitimate learning: "cooperation between the military and academic elements will be necessary to ensure that courses that carry credit are adequately conceived and presented so that they will have academic credibility." 11

Thus in 1969 the officer corps of the new Canadian Forces clearly foresaw the requirement for a range of post-secondary learning, both academic and professional, which would prepare officers for the intellectual demands of a range of professional functions spanning any officer's career.

But the CDEC was not to be. Even before the report was finalized the critics had begun to muster their counter-arguments. RMC, long the bastion of undergraduate 
officer education, was among those opposed to the new concept. While one can only speculate, it is likely that there was much angst among alumni and perhaps faculty that the venerable institution would close its doors, or worse, be repurposed and perhaps renamed as a training school for officers entering the military without a degree. ${ }^{12}$ In addition to this opposition there was also a downsizing philosophy growing in government; the last thing that National Defence should hope to do was locate a university with thousands of students and faculty in the national capital when Cabinet was insisting on reducing the number of public employees in the Ottawa area.

If the CDEC was not practicable, what of its raison d'être and its educational programmes? These seem to have been both logical and necessary, so could the Canadian Forces achieve these same results through some other avenue? The fact was that the three military colleges were well along with a number of these strategies and would over the next 40 years be able to deliver on the majority of Rowley's recommendations. The balance of this study looks at three key themes: undergraduate education suited to entry level officers; postgraduate education in disciplines of central importance to the CF; and the development of a professional masters degree which recognizes the credibility of senior and executive professional development programmes.

Broadly speaking, there are four bodies of evidence which will help explore the issues described in the previous paragraph: the efforts of the initial post-war faculty of the college to embed broad liberal education within a heavy science and engineering focused programme, along with the deliberations of the minister's Canadian Service Colleges Advisory Board (renamed the Canadian Military Colleges Advisory Board at the time of unification of the services in the mid-1960s); the reflection of policy decisions in the colleges' calendars, arguably the "advertising" vehicles of the colleges in the decades before the Internet; the RMC Board of Governors' Report of the late 1990s which sought to refocus the purpose and programmes of RMC; and finally, the expansion of the RMC faculty at the Canadian Forces College (Canada's integrated staff and war college) in Toronto. This analysis uses a range of primary sources, but at the same time includes a number of personal observations as I have been in some way a player in a number of recent events and decisions.

While RMC was not to have a degree charter until 1959, many of the post-war faculty and military leaders of the college were alive to the importance of a university setting and the quality of the associated learning. Writing in 1951, RMC history professor Richard Preston, who subsequently wrote two insightful volumes on RMC, recorded:

R.M.C. cadets live and work in contact with professors actively engaged in scientific enquiry, in research and humanities, and in literary effort. R.M.C. is like a university in that the dissemination of knowledge is undertaken in connection with the advancement of learning and is nurtured by it. In an atmosphere of inquiry the cadets are intellectually stimulated by men who are engaged in the pursuit of truth for its own sake and their environment thus blends the university and the military college. This emphasis on "academic" research is as important an innovation in the Royal Military College as is the tri-service scheme itself. ${ }^{13}$ 
The following year Preston continued this theme. In "The Humanities in Cadet Colleges," Preston argued for a general education for officers for a variety of reasons: it prepared them to take broad "imponderable challenges rather than just narrow technical work. As well, it instil[ed] societal values." But he went on to say that "introducing liberal education [had] challenges, particularly breaking out of the regimented and overstuffed nature of military college timetables. As well, in time of crisis colleges tend to concentrate on essential training versus broad education." These concerns aside, Preston was most concerned that "the general public might not realize that humanities were taught in the colleges." With respect to RMC he noted that that college did offer humanities courses similar to those found in civilian universities. His overall conclusion was that "it is important to have a well educated officer corps in order to protect civilization." 14 While Preston's turn of phrase might by today's standards seem a bit melodramatic, one must remember that he was writing at the height of the Korean War.

Debates over what sort of education the officer corps might need had in fact been raging in Ottawa and two camps had emerged. On the one hand the traditionalists argued for a continuation of the status quo - officer training, but not normally leading to a degree, with the admission of some aspirants with as little as a grade 10 education. The modernist camp felt on the other hand that an undergraduate degree was needed to equip an officer for positions of responsibility and decision-making. The problem was passed to the head of the Defence Research Board, Dr. Omer Solandt, who advised that men of limited intellectual ability could be effective in lower level posts but that higher level management and leadership positions did require higher education. However, with both the onset of the Korean War and Soviet posturing in Europe calling for large increases in forces, it was decided that this was not the time to make changes to RMC's programme which would therefore continue to focus on a blend of training and education for the majority of cadets, and a degree for engineers. $^{15}$

Discussion of RMC's programmes and the quest for a provincial charter that would follow before the end of the decade were fully in keeping with the general emphasis on education across the land and an expansion of post-secondary institutions in Ontario in the same period. ${ }^{16}$ The university was seen as an engine of economic development necessary if Canada was to play a more important role economically and politically. This notion was well understood in Ontario where in 1956 the provincial government signalled the need for expanded undergraduate education in its response to the Royal Commission on Canada's Economic Prospects. ${ }^{17}$ Indeed, 10 new universities were to open their doors between 1957 and $1965 .{ }^{18}$ Offering a degree, whether in 1959, or, as Rowley would argue in his report, making it a requirement for entry into the officer corps, was both fully in line with a broader national trend and would serve as a way of attracting and hopefully keeping the cream of young Canadians.

The blend of science, engineering and liberal arts and the existence of three streams of study was mentioned if only briefly in the RMC Calendar for 1954-5. Under the heading of "General Objectives" was the statement, "The course of instruction 
attempts to provide a sound and balanced liberal scientific and military education." ${ }^{19}$ Elsewhere the calendar indicated that cadets undertook a four-year programme in either arts or engineering. Those in the engineering track could normally expect to continue on to complete a degree in a Canadian university. First and second-year programmes were common to all streams with cadets taking English, French, math, physics, chemistry, engineering drawing, history and economics. In the upper years this cross pollination continued, if to a lesser degree, but intriguingly all cadets took a philosophy course centred on logic and exposition. ${ }^{20}$

The Canadian Service Colleges Advisory Board met for the first time in January 1955. It was a substantial group, with the Minister, the Hon. Ralph Campney, in the chair and the heads of the Royal Canadian Navy, the Canadian Army and the Royal Canadian Air Force in attendance, while the members included a range of educators or other prominent citizenry from each of the provinces. In opening the session Campney noted that: "It is to [the military colleges] that we look for the production of officers who are men both of character and of liberal education, and who will in future years be capable of bearing the burden of defence responsibility." 21

On the subject of the purpose of the programme at RMC, Col. W.R. Sawyer, the Director of Studies (in essence the principal), noted that "the objective of the course was to provide a well-rounded education in both the arts and engineering, and to combine academic with leadership training." Underscoring the unique mandate of RMC he added, "In comparing RMC to the universities, he pointed out that while RMC courses followed a university pattern, the curriculum was specially designed to meet military requirements." 22

Elsewhere in the discussions, Sawyer stated that while RMC did not give a degree it was "probably" the oldest engineering college in the dominion. ${ }^{23}$ To this the Commandant, Air Commodore Bradshaw, added that RMC was currently the fourth largest engineering school in Canada. ${ }^{24}$ In fact, however, RMC was producing its engineering degrees by sending its "graduates" to Ontario universities for a fifth year of studies, and these universities were facing enrolment pressures (brought on by a need for more university graduates to ensure economic wellbeing for the nation discussed above). Extensive discussion on the merits and risks of RMC having its own degree programmes followed, but no conclusions were reached. ${ }^{25}$

The following year at the second meeting of the advisory board Bradshaw put forward a recommendation to award a BA to those in the arts stream as it would enhance the reputation of the College and its graduates, tend to attract more applicants, and open the door for those wanting to go on to graduate studies. He also emphasized that the RMC arts programme was already equal to those at other Ontario universities, that the province would be favourably disposed to grant a charter, and that the academies of the major allies were granting degrees. Once the BA was in place, an engineering degree would follow. In making his presentation Bradshaw noted that the reason for RMC's existing fifth-year requirement for engineers had in part to do with the arts component of the RMC engineering programme (about 20 percent), curriculum which was in keeping with general recommendations for all university engineering programmes. ${ }^{26}$ 
An extensive debate ensued with two views emerging: on the one hand General Charles Foulkes, the Chairman of the Chiefs of Staff Committee and defacto senior member of the armed services, felt that there was no military requirement for a BA and that granting such a degree would draw would-be engineers way from that necessary qualification. Curiously, Foulkes, who had been one of the modernizers at the being of the decade, now seemed to have switched sides. ${ }^{27}$ It would also likely lead to increased releases from the military after three years of commissioned service when young officers would have a marketable degree and life skills to offer in the job market. On the other hand, it was thought that if cadets were achieving the requisite credits that an appropriate degree was warranted for those in the arts stream, it would make for an even recognition between arts and engineering while also serving to increase recruiting for the Services. The Minister deferred further discussion and decision. $^{28}$

The third meeting of the board in early 1957 opened with a caution from Minister Campney that defence budgets across NATO were being cut and that Canada's would be no exception to this trend. Consideration was being given "to limiting the training of general duty officers to two years beyond senior matriculation, and of permitting technical officers only to be trained through third and fourth years at RMC." ${ }^{29}$ Despite this possibility, a full discussion ensued on the granting of degrees. As had been the case the previous year, General Foulkes remained opposed to degrees as did a number of others. Discussion centred to some extent on the possibility of granting a degree in Military Science, but it was felt that this would not do much to attract applicants nor have much credibility in the general population. Once again, however, no decision was reached. ${ }^{30}$

Eighteen months were to pass before the advisory board met again and now the minister was the Hon. George Pearkes, a Progressive Conservative, who noted that as the result of a recommendation of an ad hoc committee on the Regular Officer Training Plan (under which RMC operated) chaired by navy Capt. William Landymore, RCN, policy work was moving ahead to secure degree granting authority for the RMC. ${ }^{31}$ Perhaps weighing on the committee's deliberations was evidence that Solandt's predictions about intellectual potential was starting to show up in day-to-day events. One instance involved the cohort about which Solandt had had concerns. In 1959 only 19 percent of mid ranked army officers, who would generally have joined the army at the beginning of the decade and were applying for the Canadian Army Staff College were successful on the entrance exam. Of those who were accepted 68 percent had university degrees. ${ }^{32}$

The net result of granting degrees at RMC, Pearkes was now told, would remove the need for engineering grads to attend civilian universities to complete their degrees and would thus make these new officers available for service one year sooner. ${ }^{33}$ The granting of BAs and general BScs would be possible by May 1959 with BSc (Honours) and BEngs by 1962, once some additions to equipment, labs and faculty were made. In briefing the board Col. Sawyer noted that these programmes of study had no counterparts in civilian universities. Specifically, RMC arts programmes included two years in math and a "minimum" of two years in science; there were also 
courses in gaming theory, English, French, history and economics. Science degrees included a good deal of engineering and Engineers received a bigger proportion of arts courses than in equivalent civilian programmes. ${ }^{34}$

A provincial Act Respecting the Royal Military College of Canada was passed into law on 1 January 1959. Not only did the act grant the College the authority to grant degrees in the arts, sciences and engineering, but also gave it authority to grant retroactive degrees in arts and sciences for those students having completed the programme between 1948 and 1958. This acceptance of previous studies could not but underscore the quality and validity of the content and teaching that had been put in place by RMC faculty and supported by the Department. ${ }^{35}$

Recognizing this new authority, a small modification appeared in the 1959-60 calendar, one which would not be at all obvious to a casual reader. In the section titled "Duration of the course" a brief paragraph noted that a BA or BSc would be conferred on those successfully completing a course in either of those streams, and that while a BEng would not be conferred before 1962, engineers would be offered a diploma. There was no mention of the newness of these degrees, or of the value of a degree as such. Similarly there was no mention of the opportunity for engineering students to complete a degree at a civilian university. ${ }^{36}$

In October 1959 Col. Sawyer reported to the advisory board that the charter had been granted, and that perhaps, not coincidentally, 1959 was confirmed as the best year for Regular Officer Training Plan recruiting on record. Sawyer, giving his detailed report on implementation, stated that not only would National Defence save some $\$ 870,000$ by no longer needing the fifth year of education for engineers, and explained that it was now possible to give engineers a degree in four years, with only slight curriculum reductions and modifications (two per cent reduction in the arts content and a small increase to classroom days). On a broader level he added that it was now much simpler to provide the necessary curriculum in-house rather than having to coordinate with 12 different engineering schools which had in the past taken on the fifth year students. ${ }^{37}$

Focus at RMC during 1960 was on the implementation of the engineering degree. Sawyer reported solid progress at the November 1960 meeting of the advisory board. Work had proceeded, including an independent review by the Engineers Council for Professional Development which had found "that the courses described are entirely adequate and that [RMC] should be congratulated ...." This said, there was concern by the board that cadets were now too heavily tasked with academics and that with only 17 percent of the engineering programme assigned to arts courses these officers were ending up getting a technical education. ${ }^{38}$ Maintaining this balance would be a recurring theme.

The degree streams at RMC had not been long in place when a proposal was tabled at the 1965 meeting of the board to conduct a study towards the possibility of instituting a four-year degree in business administration at the Quebec-based CMR for various reasons, including official languages and a desire to recruit more Francophones. From an organizational slant the proposal had to do with making CMR and eventually RRMC robust small universities in their own right rather than 
feeder colleges for RMC. This would do much towards increasing the quality of faculty and teaching at both colleges. A long discussion relating to officer production and degree streams followed, but ultimately the minister concluded that a study was warranted and that a report should follow at the next meeting. ${ }^{39}$

How exactly CMR would give degrees was a question requiring some exploration and the issue was discussed at the 1968 meeting of what had now become the Canadian Military Colleges Advisory Board. While CMR was a federal college and would-be university, the members were also mindful of the fact that education was a function and responsibility of the provinces. No definite plan for the charter was reached..$^{40}$

By 1970, the new programme had become a reality, but there was only the briefest mention of the new Bachelors in Administration in the opening paragraphs of the CMR Calendar. Under the heading of Duration of the Programme, a section which had existed in all colleges' calendars, there was a brief and vague mention of the new programme along with equally imprecise descriptions of the other degree paths available in all three colleges. ${ }^{41}$ Deeper into the calendar one did find a table describing three "Options" of study at CMR, one of which clearly indicated the BAdmin path. Unique to CMR was the prep year which allowed students from Quebec to complete a CEGEP equivalency. All students took courses in the social sciences, sciences and maths. There was also a one credit course in religious knowledge. The first year syllabus reflected the balanced curriculum of RMC with students in all streams completing courses in math, physics, history and psychology. ${ }^{42}$ What was not mentioned was that CMR itself did not have a charter and that the degrees would in fact be those of the University of Sherbrooke. ${ }^{43}$ This strategy allowed CMR to offer degree programmes while ensuring that the province maintained control over education. This university/college partnership presaged what by the early twenty-first century would become a common means of operation across Canada.

During these same years that the expansion of degree programmes at CMR and Royal Roads was under consideration, the advisory board had also given attention to future considerations of policy conducting far ranging discussions of the findings of the Officer Development Board. An initial discussion in late 1967 was captured in the minutes under the heading of "Military Training and the Philosophy of Curriculum Content." Much attention was focused on what the CMC degree should encompass and what should be the balance between training and education. There was general consensus that while the focus of various courses might be "Service oriented" there was every intent to ensure the general intellectual development of the cadets. RMC was not intended to be a technological training establishment but a university with a unique student body. Victoria Cross winner Lt. Col. Cecil Merritt, himself an RMC grad from the 1930s, argued enthusiastically that the curriculum of RMC should include the study of military thought in order to whet the intellectual appetite for a career in the Services; he was concerned, as were others that many young officers saw themselves first as engineers or scientists and thus were inclined to leave the service after only a minimum period of post graduation service. Allard took a slightly different slant, stating that military content in the curriculum should not be close order 
drill or other such training, but rather the development of a young officer's intellect. ${ }^{44}$

As we have seen previously, the actual ODB report was published in early 1969 and although it was not implemented some of the thinking contained in document as well as some of the realpolitik of Ottawa was visible in the public documents of 1971. The Royal Roads Calendar for that year made mention of the establishment of the Canadian Defence Education Establishment - a revised Canadian Defence Education Centre which would exist in function but not in body. ${ }^{45}$ Further the calendar provided a significantly revised statement of objectives from that which the colleges' calendars had included in the previous years. Now, in keeping with Rowley's focus on education and intellectual capability, these institutions were, among other things, to provide "a university level education in appropriate disciplines designed on a broad base to meet the unique needs of the forces" and "to improve the educational background of commissioned officers in the Canadian Armed forces by providing undergraduate and postgraduate courses in appropriate fields." ${ }^{6} 6$ The calendar went on to list in detail the various degree paths open to undergraduate and graduate students. At CMR the range of degree options now included both administration and maths and sciences. Finally, it was noted that Royal Roads itself would now offer two entry paths, a new intake gateway directly to Arts and the traditional entry scheme which could lead to a degree in engineering, sciences or arts. The Calendar indicated that a "Senior instructor" would advise cadets on which course pattern would be "most in keeping with their interest and abilities...." Regardless of the entry programme, it was pointed out that here were a range of common courses over the two years at roads including maths physics, chemistry, English, French, history, economics, psychology and computer programming. ${ }^{47}$

As mentioned earlier RMC had been created in 1876 to produce engineers for the Canadian military and for the nation. This being the case it was expected up until 1970 that all students would enter into an engineering programme of study. The reality, as seen in the Arts stream which was available even in the 1950s, was that not all potential officers were cut out for engineering or even science. This circumstance was recognized with the implementation of the Arts entry programme of which I was one of the first intake.

By the middle years of the 1970s, this relative explosion of degree options as well as the overall balance of military to academic balance within the colleges was becoming a concern and at the 1974 meeting there was agreement that a general review of degree paths, CF requirements and operating costs was in order. The advisory board's chair, Dr J.W. Hodgins, recommended a "period of consolidation," and it was agreed to put a three-year moratorium on new academic programmes. ${ }^{48}$ It would take almost two years before a review could be conducted but a report was tabled in early 1977 by the Task Force on Academic Review chaired by Dean A.C. Leonard at RMC. With a strong representation of faculty from all three colleges, their task was to review the academic programs of the three institutions in relation to the knowledge competencies needed by graduates' employer - the Canadian Armed Forces. Among their conclusions, they recommended dropping Chemical Engineering at RMC, and the continuation of the highly useful Engineering Management; and they also proposed 
the integration of English, French, History and International Studies programmes at RMC into a programme of military and strategic studies. These were tough recommendations as in some cases they called for the dismantling of complete programmes and departments, and met with much opposition from faculty. ${ }^{49}$ Ultimately it was the Engineering Management programme that was dropped, and while a Military and Strategic Studies programme was introduced none of the other arts degrees were dropped.

Work on the BA (Military Studies) was well along by 1979 although it was noted in that year's board minutes that there was some concern that such a degree would not be "saleable" with cadets nor would its purpose be necessarily popular with Canadians at large..$^{50}$ The 1981 RRMC calendar laid out the modalities of the two undergrad programmes now offered on the west coast. The BA in what was now called Military and Strategic Studies was designed to give cadets a broad grounding in subjects related to the title of the programme which overall was "intended as a solid foundation for subsequent officer development through individual study in disciplines relating to war and the military." 51 The BSc in Physics and Oceanography was open to cadets from all three colleges. While it provided specialization in these two fields it was more generally intended to "produce general service officers who are capable of working in land, sea and air environments; who have a sound knowledge of basic physics, chemistry, mathematics and an appreciation of general engineering subjects and, who will appreciate those aspects of the social sciences and humanities relevant to the military profession and ethic." 52 Students of any of the colleges' streams could apply to the RRMC MSS programme, while only those who had started in engineering and science qualified for entry into the unique Oceanography programme. Unlike Oceanography which was only offered at RRMC, all three colleges had instituted MSS programmes. ${ }^{53}$ What was less apparent, particularly for one looking for the basis for those degrees, was that fact that Royal Roads had received a charter from the province of British Columbia in 1975 to grant undergraduate degrees. ${ }^{54}$ With that charter all three colleges now had four-year programmes leading to a baccalaureate.

It was only in 1987 that the Advisory Board received a detailed update on the three MSS programmes. Each was slightly different, the RRMC programme, for example, taking advantage of the geographic nearness of the Pacific Rim to focus on Russia, China and Japan. All three programmes were interdisciplinary in content and at RMC there was a strong synergy with the Masters in War Studies, itself interdisciplinary, which had been introduced in the late 1960s and is discussed in more detail below. Despite what would seem an attractive programme for budding officers only the CMR faculty gave the MSS programme full endorsement. At RRMC cadets apparently still found the name of the programme problematic as it had no obvious relevance outside a military career and at RMC the faculty were apparently more interested in teaching more mainstream Arts programmes. It was further observed that the programme, despite being designed for the service officer, was not well subscribed and that offering it in all three colleges was to some degree overkill, particularly when there was not explicit service requirement for such a specialization. This would appear a curious line of argument as both the Leonard study and a subsequent review 
by the advisory board had recognized, despite the lack of a hard requirement, that an MSS programme would be "useful ... in terms of professional military development/ background." "I5 It was arguably akin to the medical profession saying that there was no real need for a life sciences baccalaureate.

We will review recent developments in the undergraduate programme later, but some conclusions are appropriate here. First, responding to the rationale that young officers could better acquit their responsibilities armed with a liberal education, RMC had pushed for and found approval, both at the Department of National Defence and within the provincial education systems of Ontario, Quebec and British Columbia. While the range of degrees was not well defined by the Canadian Forces, the three colleges still offered a reasonable span of education across Engineering, Science and Arts and Social Sciences. In so doing RMC and its sister institutions had ably met Rowley's goal of undergraduate learning for new officers. ${ }^{56}$

If we now turn to the creation of graduate education within RMC, here too we find that the College's leadership had taken action and produced results before the ink was dry on Rowley's recommendations. The first graduate course of any sort was History 500 , a course in naval history taught by a visiting prof, Brian Tunstall, from the Royal Naval College in Greenwich England in 1965-6 to two military staff, WAB Douglas and BD Hunt. By the following year 12 graduate courses in science and engineering were underway. The first graduate degree (Mechanical Engineering) was awarded that same year. The first MA was awarded in 1967 and the first MSc came in 1971.57

At the 1965 meeting of the CSCAB there had been a rather unfocused discussion on post-graduate programmes, looking at the placement of graduate studies within an officer's career and at the subsequent employment of officers with such education. Col Sawyer pointed out that RMC had started a small PG programme for officers posted to the college on staff; there were nine students in all, two in arts, seven in engineering. The advantage of offering graduate programmes to RMC, he pointed out, was the ability to interest high quality faculty who were attracted by the possibility of having graduate students, as would be the case in any other university. Other than the possibility that some PG grads could become useful defence scientists, a small civilian career path within the Department of National Defence, those discussing the PG concept did not see much value to the military or department as a whole. ${ }^{58}$

While graduate programmes were advertised in the 1965-66 RMC calendar, there was no graduate section within the calendar or course listings as such. Rather it was simply indicated that a graduate degree in arts, sciences or engineering would require a minimum of two, and normally more, approved courses at the graduate level..$^{99}$

The calendar for 1966-67 contained a full if brief graduate section. Course requirements remained the same but now there were a range of history, political science and math courses presented with course numbers and descriptions. Significantly, of the three history courses History 502 dealt with Canadian Defence Policy while History 504 examined the theory of war. ${ }^{60}$ These were clearly related to the professional knowledge requirements of serving officers.

The 1967-8 calendar reflected a significant expansion of graduate courses. A "War Studies" Programme was now up and running. As mentioned above, this was 
an interdisciplinary programme which focused on the phenomenon of war and borrowed its name from the highly successful programme of the same name at King's College London. The degree required the completion of four courses and a major research project or thesis and was open to applicants with a degree in the arts, sciences or engineering. No honours degree was required (although this was the basic stipulation for entry into other graduate programmes) although the applicant did need to show second class honours in his/her final undergrad year. The range of War Studies courses was impressive, including international relations, defence economics, civil military relations and international public law in addition to courses in defence logistics, resources and nuclear physics and chemistry. ${ }^{61}$ This was clearly a degree related to the profession of arms and very much along the lines of what the ODB report would recommend not long after.

By 1987 some 256 graduate degrees had been awarded by RMC (Arts 5; War Studies 42; Maths and Sciences 26; Engineering 183). ${ }^{62}$ The statistics show a preponderance of degrees in Engineering and this was related to the hard engineering skills and knowledge which various engineering specialties within the military could define: mechanical engineers, for example could be used in a variety of research jobs related to designing and testing of new equipment, while electrical engineers with knowledge of advanced wireless theories were instrumental in designing and implementing new radio systems. But there was also a desire for non-engineering graduate qualifications. A CMCAB review of the complete system during this same year noted that there was a "groundswell of support amongst higher headquarters staffs for more advanced studies opportunities for senior officers in the operational classifications." A small number of places was established so that officers could undertake either a Masters in War Studies at RMC, a similar degree (usually International Relations or Political Studies), or even an MBA or MPA if they were accepted into a civilian programme. $^{63}$

Overall, as was the case for undergraduate education, by 1990 RMC was filling the graduate education needs of the Canadian Forces, with large numbers of officers either earning science and engineering qualifications related to their primary employment as well as Rowley's "sprinkling" of non-specialists. Things would change within the next few years as outside factors and forces redefined the learning needs of the military.

The repercussions of the Somalia Inquiry, wherein the military was found by the civilian commissioners to have serious flaws in both its leadership and ethics. ${ }^{64}$ of the mid-1990s were to have their effects on RMC and its programmes, but these came at the same time as the decisions to close Royal Roads and CMR as well as the Staff School and the National Defence College. In the latter case it has been long suggested that the decision was made following a high level meeting at which the Deputy Minister, Robert Fowler, asked assembled senior generals and admirals including the Chief of Defence Staff which if any of them had attended NDC. None had, and from this it was concluded that the programme was "nice to have" and not essential for the development of senior leaders. The closings were not announced in the 1995 defence review, but rather in a preceding budget update. The Cold War was at an end and 
there was, after all, a peace dividend for the taking. ${ }^{65}$ The net result was to leave only RMC and the Canadian Forces College, the military's professional graduate school, to provide whatever education might be deemed necessary for the officer corps.

Although the Canadian Forces had started in 1994 to review the requirements for learning programmes under the mandate of the Officer Development Review Board $^{66}$ it was the 1997 Report of the Minister to the Prime Minister, based largely on the findings from the Somalia findings, ${ }^{67}$ and a follow-on set of recommendations by the Minister's Monitoring Committee which were the public face of changes. ${ }^{68}$ As will be discussed later, for RMC there was a need to refocus undergrad programmes using what was called the "Balanced Excellence Model," incorporating significant cross programme content, not unlike what had been present in the 1950 s. $^{69}$

At the other end of the professional learning spectrum, military faculty at the Canadian Forces College were by 1996 in the process of redesigning senior and executive level military education programmes, fundamentally rethinking how these should be delivered. ${ }^{70}$ The premise presented to various approval bodies was that the content of the senior programmes, focusing on the higher management questions of defence policy and military operations, was not fundamentally wrong, but that the material had been presented largely without intellectual rigour thereby putting in doubt the actual learning. The previous National Defence College programme, a curriculum of 10-months duration, had until its last year included a staggering 114 days of travel but very little in written work. That college had been closed at the same time that Royal Roads and CMR shut their doors. Why not, it was thought, build the new programmes around graduate level learning practices - seminars, papers, symposia and the like — and add a few days of experiential learning, i.e. visits, if these could be pedagogically justified and firmly tied to learning objectives. Moreover, if legitimate graduate learning was going on, would it not be possible to offer RMC graduate degrees? When this model was presented to RMC's Dean of Arts (responsible for War Studies) and the Dean of Continuing Studies they provided full support. From here it was not much of a stretch to think in terms of Rowley's vision of graduate credits for graduate level learning.

That however, was a horse of a different stripe and here there was some concern by the larger faculty at RMC that the quality of the College's degrees might be diluted. After some considerable refinement, including the creation of a robust multidisciplinary Department of Defence Studies of the Royal Military College at the Canadian Forces College, it became possible to offer an accredited Masters in Defence Studies in association with the Command and Staff Course for mid-career officers. An equally accredited Master of Arts in Defence Management and Policy (and in recent years an MPA) in conjunction with the National Security Programme, a programme intended for officers and civilian students moving into executive appointments, was also introduced. Students were also able to earn credits towards either of the MA in War Studies or the MBA, although on a more limited basis. In effecting this change in the delivery and intellectual quality of professional programmes RMC had contributed materially to the achievement of Rowley's third theme of graduate credit for programmes of sufficient rigour. 
As mentioned above, it was in 1997 that staff and faculty at RMC began to plan for the implementation of the recommendations of the Minister's Report and the Report of the Minister's Monitoring Committee. Among the first of these came the formation of a- newly struck Board of Governors, in effect replacing the CMC Advisory Board which had not met since 1995, and a "Core Curriculum" report. This report called for a significant curriculum overhaul, reintroducing the substance and the ideals of a liberal education for all graduates of the college. ${ }^{71}$ The report is cited here in considerable detail as a model of broad learning at the undergraduate level.

[The] core curriculum contains within it two very separate themes. The first theme is the minimum standard for mathematics and science (which is also seen as encompassing logic and information technology) which all officers need to have. The second theme is the basic requirements in the humanities, social sciences and applied social sciences which underlie the profession of arms in a Canadian context.

Recommendation 1 [of the Minister's Report] suggests that the militarily relevant core curriculum should constitute approximately 30 percent of the academic pillar of a typical degree. ${ }^{72}$ On careful examination we believe that the percentage should be higher and can be higher with minimal disruption.

An acceptable minimum mathematics, science, IT and logic program has been assembled for Arts students, and occupies 7-8 half year courses. It has a high degree of rigor. Science and Engineering students will exceed this minimum standard, which consists of:

\begin{tabular}{|l|l|}
\hline Calculus & 2 course equivalents \\
\hline Logic and Algebra & 1 course equivalent \\
\hline${ }^{*}$ Information Technology & 1 or more course equivalent \\
\hline${ }^{*}$ Physics & 1 or more course equivalent \\
\hline${ }^{*}$ Chemistry & 1 or more course equivalent \\
\hline${ }^{*}$ Other Math & 0 or more course equivalent \\
\hline
\end{tabular}

To a total of at least 7 course equivalents

* Depending on prerequisites, these may vary; also an additional course may be recommended in some cases.

An acceptable minimum program for the humanities, social sciences and applied social sciences relevant to officership has been assembled. It is the minimum for all streams, and occupies 10-12 half year course equivalents. It can be met by the Engineering programs. Its centerpiece is a rigorous new pair of complementary courses entitled "Canada", in AY1 for Arts and in AY2 for others. In summary: 


\begin{tabular}{|l|l|}
\hline Leadership and Ethics & 3 courses \\
\hline \multirow{2}{*}{ Canada } & 4 course equivalents (Arts) \\
\cline { 2 - 2 } & 2 course equivalents (Others) \\
\hline Canadian Military History & 1 course \\
\hline Strategy and Military Theory & 1 course \\
\hline International Relations \& Transnational Culture & 1 course \\
\hline Language and Culture & 2 courses \\
\hline
\end{tabular}

The minima in these two themes represent about 17-19 half courses, or $30-40 \%$ of an undergraduate degree, depending upon the program. ${ }^{73}$

If one removes the two courses relating to military history and theory from the core curriculum, the studies that are required could arguably form a basis of success for any young Canadian setting out into Canadian or international society.

From the foregoing it seems clear that RMC, regardless of the presence or absence of the management structure recommended in 1969, has understood the importance of Rowley's three central thrusts. A decade before Rowley recommended degrees for the officer corps, a sentiment repeated three decades later in the wake of the Somalia debacle, RMC had sought the first of three degree charters. Then, even as Rowley was beginning his study, RMC quietly introduced graduate learning in a range of programmes germane to the profession. And finally, in the 1990s a group of senior faculty at RMC and the Canadian Forces College facilitated the introduction and successful accreditation of a professional master's programme recognizing the intellectual value of the learning taking place in Toronto.

Rowley had envisaged in the creation of the Defence Education Centre a unified learning organization - "one officer factory." RMC, focusing on quality learning programmes for the Canadian military has, one could argue, make good on that vision.

\section{Notes}

1 Richard Preston, To Serve Canada: A History of the Royal Military College Since the Second World War (Ottawa: University of Ottawa Press, 1991), 14-5.

2 See Randall Wakelam and Howard Coombs, eds. The Report of the Officer Development Board: Maj-Gen Roger Rowley and the Education of the Canadian Forces (Waterloo: Laurier Centre for Military Strategic and Disarmament Studies, 2010). Hereafter ODB Report. Alternatively, please see Randall Wakelam "Officer Professional Education in the Canadian Forces and the Rowley Report, 1969," Historical Studies in Education/ Revue d'histoire de l'éducation, 16, 2 (2004): 287-314. Hereafter, "Officer Professional Education."

3 Wakelam and Coombs, eds., ODB Report, 4.

4 Wakelam and Coombs, eds., ODB Report, 40-41.

5 Wakelam and Coombs, eds., ODB Report, 38. 
6 For a more complete discussion on the requirement for a degree readers may wish to consult "Officer Professional Education." While it is relatively easy to identify the skills and knowledge required to successfully complete a particular task and subsequently to develop the associated and measurable training there has been less success in demonstrating the need for the general intellectual capabilities normally associated with an undergraduate and more so with graduate degrees. Yet, the ability to think critically and creatively was exactly what senior officers knew from their own experiences was required of the officer corps.

7 Until the late 1960s only RMC had a degree charter and students from RRMC (Victoria, B.C.) and CMR (St-Jean, Quebec) would transfer to RMC after their first two years of university studies.

8 In contemporary military parlance a 'course' constituted any learning activity ranging in duration from a few days to over a year. At one point later in this study the four-year programme at RMC is referred to as 'a' course.

9 This is discussed in Canada, Department of National Defence, Report of the Officer Development Board Vol. 2 (Ottawa: Department of National Defence, 1969), 317-20. Copies of the original report can be found in the libraries of the Royal Military College and the Canadian Forces College, the latter in Toronto.

10 Wakelam and Coombs, eds, ODB Report, 87.

11 Wakelam and Coombs, eds, ODB Report, 88.

12 Canada, Report of the Officer Development Board Vol. 2, 165.

13 Richard Preston. "Tri-Service Education at Canada's R.M.C," offprint from R.M.C. Review, Vol. XXXII, 1951. RMC Massey Library Archives, Preston Papers, Box 1, File 1. np.

14 Richard Preston. "The Humanities in Cadet Colleges," R.M.C. Review, Vol. XXXIII, 1952, 86-95. Offprint in Preston Papers, Box 1, File 1.

15 Peter Kazurak, "Concepts of Professionalism in the Canadian Army, 1946-2000: Regimentalism, Reaction, and Reform," Armed Forces \& Society 37(1), 97-9.

16 See Paul Axelrod, Scholars and Dollars: Politics, Economics, and the Universities of Ontario, 1945-1980 (Toronto: University of Toronto Press, 1982), and A.B. McKillop, Matters of Mind: the University in Ontario, 1791-1951 (Toronto: University of Toronto Press, 1991).

17 Axelrod, 20, 86-87.

18 McKillop, 564-66.

19 RMC Calendar 1954-55, 13.

20 RMC Calendar 1954-55, 26-32.

21 Library and Archives Canada (LAC) RG24 1995-96/314 Box 1. Minutes of First Meeting of CSCAB, 31 January-1 February 1955, Appx A, pg 2.

22 LAC RG24 1995-96/314 Box 1. Minutes of First Meeting of CSCAB, 31 January-1 February 1955, 4-5.

23 LAC RG24 1995-96/314 Box 1. Minutes of First Meeting of CSCAB, 31 January-1 February 1955, Appx E.

24 LAC RG24 1995-96/314 Box 1.Minutes of First Meeting of CSCAB, 31 January-1 February 1955, Appx B.

25 LAC RG24 1995-96/314 Box 1. Minutes of First Meeting of CSCAB, 31 January-1 February 1955, 9-11.

26 LAC RG24 1995-96/314 Box 1. Minutes of Second Meeting of CSCAB, 24-25 February 1956, 6-9.

27 Kazurak, 97.

28 LAC RG24 1995-96/314 Box 1. Minutes of Second Meeting of CSCAB, 24-25 February 1956, 9-16.

29 LAC RG24 1995-96/314 Box 1.Minutes of Third Meeting of CSCAB, 8-9 March 1957, 1 . 
30 LAC RG24 1995-96/314 Box 1.Minutes of Third Meeting of CSCAB, 8-9 March 1957, 18-20.

31 LAC RG24 1995-96/314 Box 1.Minutes of Fourth Meeting of CSCAB 10-11 October 1958, 3.

32 Kazurak, 99

33 LAC RG24 1995-96/314 Box 1.Minutes of Fourth Meeting of CSCAB 10-11 October 1958, 3.

34 LAC RG24 1995-96/314 Box 1.Minutes of Fourth Meeting of CSCAB 10-11 October 1958, 26-7.

35 Richard Preston, Canada's RMC: A History of the Royal Military College (Toronto: University of Toronto Press, 1969), 348.

36 RMC Calendar 1959-60.

37 LAC RG24 1995-96/314 Box 1. Minutes of Fifth Meeting of CSCAB, 30-1 October 1959 ,

38 LAC RG24 1995-96/314 Box 1. Minutes of Sixth Meeting of CSCAB, 4-5 November 1960, 16-18.

39 LAC RG24 1995-96/314 Box 1. Minutes of Ninth Meeting of CSCAB, 12-3 November 1965, 36-44.

40 LAC RG24 1995-96/314 Box 1. Minutes of Eleventh Meeting of CMCAB, 27-8 November 1965, 60-1.

41 CMR Calendar 1970-71.

42 CMR Calendar 1970-71.

43 This arrangement would not be presented to the board in any substance until its 1973 meeting. LAC RG24 1995-96/314 Box 1. Minutes of Thirteenth Meeting of CMCAB, 23-5 February 1973, Anx A, 4.

44 LAC RG24 1995-96/314 Box. Minutes of Tenth Meeting of CSCAB 17-18 November 1967, 36-9. See also Special Meeting of the Canadian Military Colleges Advisory Board, 1 November 1969.

45 RRMC Calendar 1971-72, 2.

46 RRMC Calendar 1971-72, 2-4.

47 RRMC Calendar 1971-72, 24-6.

48 LAC RG24 1995-96/314 Box 1. Minutes of Fifteenth Meeting of CMCAB, 15-17 March 1974, 21-3.

49 Richard Preston, To Serve Canada: A History of the Royal Military College Since the Second World War (Ottawa: Minister of Supply and Services, 1991), 132-6.

50 LAC RG24 1995-96/314 Box 1. Minutes of Twentieth Meeting of CMCAB, 5-6 April 1979, 6-7.

51 RRMC Calendar 1981-82, 40.

52 RRMC Calendar 1981-82, 37.

53 RRMC Calendar 1981-82, 40-1.

54 LAC RG24 1995-96/314 Box 1. Minutes of Sixteenth Meeting of CMCAB, 18-20 April 1975, 14. RMCC's charter was confirmed in the minutes of the 1975 meeting of the CMCAB. LAC RG24 1995-96/314 Box 1. Minutes of Seventeenth Meeting of CMCAB, 27-29 March 1976, Appx A, 3. The following year it was confirmed that the CMC agreement with Sherbrooke, while provisional, could proceed.

55 LAC RG24 1995-96/314 Box 2. Minutes of Twenty-Eighth General Meeting of CMCAB 9-10, April 1987, 7-9.

56 At least for those new officers entering the military via one of the three military colleges. There would continue to be entry programmes which did not require a degree, or at least part of one, until very recently.

57 Preston, To Serve Canada, 66. 
58 LAC RG24 1995-96/314 Box 1. Minutes of Ninth Meeting of CSCAB 12-3 November 1965, 33-6.

59 RMC Calendar 1965-66, 41.

60 RMC Calendar 1966-67.

61 RMC Calendar 1967-68, 222-5

62 Preston, To Serve Canada, Appendix P.

63 LAC RG24 1995-96/314 Box 2. Minutes of Twenty-Seventh General Meeting of CMCAB, 9-10 April 1987.

64 Canada, Department of National Defence. Dishonoured Legacy: The Lessons of the Somalia Affair (Ottawa: Department of National Defence, 1997).

65 LAC RG24 1995-96/314 Box 2.Minutes of Thirty-Fifth General Meeting of CMCAB, 13-16 April 1994, 7-8.

66 Canada, Department of National Defence. Report of the Officer Development Review Board (Ottawa: Department of National Defence internal document, 1995). The Chair of the ODRB was Lieutenant-General Robert Morton.

67 Hon. M. Douglas Young, "Report to the Prime Minister on the Leadership and Management of the Canadian Forces" (Ottawa: Department of National Defence internal document, 25 March 1997).

68 Hon. John Fraser. "Minister's Monitoring Committee on Change in the Department of National Defence and the Canadian Forces Final Report-1999" (Ottawa: internal document, 1999).

69 RMC Board of Governor's [sic] Study Group, "Review of the Undergraduate Program at RMC - Balanced Excellence: Leading Canada's Armed Forces in the New Millennium" (Kingston, Department of National Defence internal document, 30 April 1998).

70 The author was one of a small team of curriculum designers and much of the following paragraphs are drawn from personal experiences. Work of this team is described in Wakelam, "Senior Professional Military. Education for the Twenty-First Century" Canadian Defence Quarterly, vol. 27 no. 1 (Autumn 1997), 14-18.

71 RMC Board of Governor's [sic] Study Group, "Review of the Undergraduate Program at RMC - Balanced Excellence," 36.

72 While beyond the scope of this paper it should be understood that the undergraduate degree awarded by RMC involves four competencies (called pillars) each of which must be satisfied for the awarding of the degree and its associated military credential: a four year undergraduate programme, a functional level of language competency in both official languages, a high level of physical fitness, and proven leadership ability.

73 BOG Core Curriculum Report, Executive Summary, http://www.rmcc.forces.gc.ca/ bg-cg/rep-rap/cc-peb/es-sommaire-eng.php, accessed 25 February 2014. See also an abridged version of these tables in RMC Board of Governor's [sic] Study Group, "Review of the Undergraduate Program at RMC — Balanced Excellence," Annex F. 